given in this paper, and it appears that the effect was observed and described by Savart as early as 1839 .

Queen's University, Belfast, June $2 \mathrm{r}$. W. B. MORTON.

\section{An Algebraical Identity.}

THE values of the coefficients of $\mathrm{Y}$ and $\mathrm{Z}$ are given in Prof. Mathew's "Theory of Numbers," p. 218 , for the primes 3 to $3 \mathrm{I}$. I have calculated the values for the primes 37 to 61 by the method given by Prof. Mathews on p. 216 of his book. My result in the case of $p=37$ agrees with that given in NATURE of June 9, p. 456 . The other results are as follows, the coefficients being given to the middle term inclusive when that exists, and in the other case to the first of the pair of terms at the middle :-

$$
\begin{gathered}
p=4 \mathrm{I} ; \mathrm{Y}, 2, \mathrm{I}, \mathrm{II}, \mathrm{I} 6, \mathrm{I}, 29,30,22,36,34,20 ; \\
\mathrm{Z}, \mathrm{I}, \mathrm{I}, 2,4,3,4,6,4,4,6 .
\end{gathered}
$$

The first case where Legendre's rule fails is $p=4 \mathrm{I}$. H. C. Pocklington.

5 Well Close Place, Leeds, June I2.

ThE result for $p=37$ given in Nature of June 9 , p. 456 , was found to conform to Legendre's rule; since this rule fails in the case of $p=61$, it is interesting, as noted by Prof. Mathews, to know if this is the lowest prime for which the rule fails.

I have worked out the case for $p=4 \mathrm{I}$, and find the expression of the 2oth degree in $x$ for $\mathrm{Y}$ to have the following coefficients :-

$$
2+I+I I+I 6+I 4-12-I I-I 9-5-7+20-7-5
$$

$$
-\mathrm{I} 9-\mathrm{II}-\mathrm{I} 2+\mathrm{I} 4+\mathrm{I} 6+\mathrm{II}+\mathrm{I}+2 .
$$

And since $\mathrm{X}$ is of the 4oth degree in $x$, each coefficient being $+\mathrm{I}$, I find $\left(\mathrm{Y}^{2}-4 \mathrm{X}\right) / 4^{\mathrm{I}}$ of the $3^{8 \text { th }}$ degree in $x$ with the following coefficients:-

$$
\begin{aligned}
& \mathrm{I}+2+5+8+\mathrm{I} 2+2-\mathrm{I} 2-28-20-\mathrm{I} 4+\mathrm{I} 5+\mathrm{I} 8+\mathrm{I} 9 \\
&-24- 23-36+9+28+72+28+9-36-23-24+\mathrm{I} 9 \\
&+\mathrm{I} 8+\mathrm{I} 5-\mathrm{I} 4-20-28-\mathrm{I} 2+2+\mathrm{I} 2+8+5+2+\mathrm{I} .
\end{aligned}
$$

Putting $x=1$, the sum of these coefficients equals -4 , hence $\left(\mathrm{Y}^{2}-4 \mathrm{X}\right) / 4 \mathrm{I}$ cannot be a square, so that the rule fails, $4 \mathrm{I}$ being the lowest prime for failure.

Stonyhurst College, June I7. J. Cullen, S.J.

\section{Artefacts and their Geological Age.}

In Nature of June 9, p. 458, Mr. J. Reid Moir describes some flint implements found embedded in the surface of the ferruginous "pan " at the base of the cliff near Sheringham, and he bases certain conclusions upon this find. From his description of the occurrence of the flints it seems clear that in this case they may not be of the same age as the "pan," in the upper surface of which they were found embedded. A little while ago, on the beach at Flamborough, a small deposit of ferruginous conglomerate was found, in which there was embedded a typical Neolithic "scraper," as well as several pebbles, and the conglomerate proved to be formed upon a horseshoe. But no one here assumed that the horseshoe was Neolithic in date, or that the scraper was made during the past fifty years. More recently, on an excursion to South Ferriby, on the Humber shore, firmly embedded in a ferruginous "pan," immediately at the base of a cliff of Boulder Clay, was a trouser button. It had to be extracted with a hammer. But no Yorkshire geologist is likely to write to NaturE to try to prove that pre-Glacial man in the Humber district wore trousers. $T$. SHEPPARD.

The Municipal Museum, Hull, June 27.

\section{Iron Currency-Bars.}

In Nature of May 19, p. 372, reference is made to iron currency-bars and "early British water-clocks." The discovery of the true nature of the currency-bars is not, as is implied, a recent one, but was made in I905 by Mr. Reginald Smith (see his paper, Proceedings of the Society of Antiquaries, vol. xx., pp. I79-94). Similarly, the "early British water-clocks" were first authoritatively dealt with by Mr. Smith in 1907 (see his paper, ibid., vol. xxi., pp. 319 sqq.) I understand that Dr. Newton Friend made this quite clear in the paper referred to, and gave his references.

It may be of interest to add that a hoard of currency-bars has recently been found near Winchester, and that the site is now being excavated by a band of volunteers under the direction of $\mathrm{Mr}$. R. W. Hooley, hon. curator of the Winchester Museum. The currency-bars were exhibited at a recent meeting of the Society of Antiquaries.

June 20.

O. G. S. CRAWFord.

\section{History of the Churn.}

IN No. 23 of the Agricultural Ledger, issued by the Government of India, and published in July, 1895 , there is a précis of official correspondence on the Indian churn which begins: "In a letter addressed to the Government of India, Herr B. Martiny, of Berlin, asked for information regarding the Indian Churn. He there announces that he is engaged writing a history of the Churn, and is desirous of obtaining certain particulars regarding 'the old Indian Churn,' of which he furnished a drawing." Has this "History of the Churn" been published in book form, or in the journal or transactions of any society? May I ask readers of NATURE if they can afford any information on the subject? If Herr Martiny addressed similar communications about native or ancient forms of churns to European, American, and Far Eastern Governments, and had his inquiry as fully replied to as it was by the Government of India, there must be pigeon-holed somewhere a mass of interesting data.

June 17 . 